\title{
No tillage and sugar beet foam amendment enhanced microbial activity of degraded acidic soils in South West Spain
}

\author{
Paloma León $^{\mathrm{a}, *}$, Rafael Espejo ${ }^{\mathrm{a}}$, Clara Gómez-Paccard ${ }^{\mathrm{a}}$, Chiquinquirá Hontoria ${ }^{\mathrm{a}}$, \\ Ignacio Mariscal $^{\mathrm{a}}$, Giancarlo Renella ${ }^{\mathrm{b}}$, Marta Benito ${ }^{\mathrm{a}}$ \\ a Departamento de Edafología, E.T.S.I. Agrónomos, Universidad Politécnica de Madrid, Avda. Complutense s/n, 28040 Madrid, Spain \\ ${ }^{\mathrm{b}}$ Dipartimento di Scienze delle Produzioni Agroalimentari e dell'Ambiente (DISPAA), Università degli Studi di Firenze, Italy
}

\section{A R T I C L E I N F O}

\section{Article history:}

Received 6 June 2016

Received in revised form 13 September 2016 Accepted 14 September 2016

Available online $\mathrm{xxx}$

\section{Keywords:}

Acid soil

Ca-amendment

No tillage

Microbial activity

Soil enzyme activity

\begin{abstract}
A B S T R A C T
Ca-amendments are commonly applied to improve acid soils, whilst no-tillage (NT) has been widely recommended in soils where conventional tillage $(\mathrm{CT})$ has led to losses of organic matter. However, the potential interactions between the two treatments are only partially known. Our study was conducted on a degraded soil located in SW Spain, in order to assess if the combination of Ca-amendment plus croptillage provides long term soil amelioration on microbial activity. To this end the effects of four different combinations of Ca-amendment and crop-tillage on selected key soil microbial properties were analyzed. The experimental design was a split-plot with four replicates. The main factor was the application or not of a Ca-amendment, sugar foam (SF) and control (C), and the second factor was crop-tillage, no tilled improved pasture (no tilled-IP) and conventional tillage forage crop (tilled-FC). Soil samples were collected from 2 soil depths after 7 years since the first SF application and after 1 year from a repeated SF application. The use of the Ca-amendment meant a higher $\mathrm{pH}$ although this effect was not found in the combination Ca-amendment plus no-tilled. Total organic carbon (TOC) was highly influenced by tillage, being higher for no tilled plots. The interaction found between tillage and amendment suggested that the beneficial effect of the $\mathrm{Ca}$-amendment on organic carbon is lost after tillage practices. A positive effect on microbial biomass carbon (MBC) was found after a second SF application for the no tilled plots in the upper layer however the effect was opposite in the deepest layer where no differences in TOC were found. After a year from a repeated SF application, a clear positive effect of no-tilled was observed on $\beta$-glucosidase, $\beta$-glucosaminidase and urease activities at the superficial layer. This fact was not found in these enzymatic activities when the amendment application effect was studied but an interaction between tillage and amendment showed that the Ca-amendment plus no-tilled combination was the most favorable option to increase the activities of these enzymes. Values of dehydrogenase were higher in amended plots than in control for both soil depths regardless of the sampling date, showing a pH effect on its activity. From our findings, no tillage plus a Ca-amendment appears to be the most suitable choice for ensuring suitable production, through the accumulation of soil organic matter (SOM) and the improvement of biological properties.
\end{abstract}

(c) 2016 Elsevier B.V. All rights reserved.
Abbreviations: SF, sugar foam; C, control; No tilled-IP, no tilled Improved pasture; Tilled-FC, forage crop; OM, organic matter; RF, rock fragments $(>2 \mathrm{~mm}$, mainly $2-30 \mathrm{~cm}$ ); nd, not determined; ND, not detected; TOC, total organic carbon; TN, total nitrogen; MBC/TOC, microbial biomass carbon/TOC; Gls, $\beta$-glucosidase activity; DHA, dehydrogenase activity; Glm, $\beta$-glucosaminidase activity; Ure, urease activity; U, soil use; A, soil amendment; ${ }^{* * *}$, correlation is significant at the 0.001 level; **, correlation is significant at the 0.01 level; *, correlation is significant at the 0.05 level; ns, not significant.

* Corresponding author.

E-mail address: palomalngd@gmail.com (P. León).

\section{Introduction}

Soil degradation caused by intensive agriculture leads to reduction of soil fertility due to changes in physical and chemical soil properties, as well as in microbial activity. In acidic soils, where the main constraints for crop production are Al toxicity and $\mathrm{Ca}^{2+}$ deficiency (Kochian et al., 2005), with the most apparent effects being reduced root and shoot growth (Menzies, 2003), traditional tillage and reduced SOM can further aggravate the limiting conditions for plant growth through reduced nutrient content and microbial activity, and also reduced soil buffering capacity. 
This is the case of the ancient Ultisols in the Cañamero's raña surface, located in SW Spain, where land use change from natural vegetation to intensive rye, vetch, cereal vineyards and olive cultivation, has caused SOM depletion, accelerated acidification and increased $\mathrm{Al}$ solubilisation. In a study conducted by GómezPaccard et al. (2013), the combination of no tillage (NT) with a Carich soil amendment has proven to be a suitable management to recover soil quality of the Cañamero's raña soil, with SOM accumulation playing a major role in improving soil chemical properties. In particular, the amendment induced neutralization of the soil $\mathrm{pH}$ value and reduced the Al toxicity and NT allowed to increase the particulate organic carbon (POC), TOC and glomalin content in the soil surface layer. Concomitantly, lime provides $\mathrm{Ca}^{2+}$ and generates $\mathrm{OH}^{-}$ions that neutralize the acidity, leading to precipitation of $\mathrm{Al}$ and $\mathrm{Fe}$ as insoluble $\mathrm{Al}^{-}$or $\mathrm{Fe}$ hydroxides. Buffering capacity is one of the most important soil properties that can be changed by incorporation of various organic and inorganic amendments, including crop residues, compost, manures, sludge or lime. Traditionally, lime has been used to buffer excessive soil acidity, but the pressing need to reduce the environmental impact of agronomic practices and to maximize waste recycling in the perspective of a circular economy in the agro-ecosystems, has encouraged scientists and farmers to test different industrial byproducts as alternative liming agents. Sugar beet foam (SF) results from the purification-flocculation of colloid matter from the liquor extracted from sugar beet. In this process, slaked lime and carbon dioxide are used to purify the liquors and after filtering, a byproduct rich in $\mathrm{CaCO} 3$ and organic matter is obtained. The annual production of SF in Spain is around 300.000T on average (Peregrina-Alonso, 2005). This by-product is considered free of pathogens because the temperature reaches $90^{\circ} \mathrm{C}$ during the process. SF acts preferentially on the surface horizons when applied to soil and it has been proven to be effective in neutralizing the excessive acidity of soils in several studies (Garrido et al., 2003; Vanderlinden et al., 2006; Gómez-Paccard et al., 2013).

Microbial biomass and enzymatic activities are reduced by soil acidification mainly through the negative selection of acidsensitive microorganisms (Rousk et al., 2010a, 2010b), and by inhibition of enzymes with $\mathrm{pH}$ optima in the neutral alkaline $\mathrm{pH}$ range (Renella et al., 2007a) which limits SOM decomposition and nutrient mineralization. Significant increase of soil microbial biomass and microbial diversity in acidic soils by organic manure, mineral fertilizers, and man-guided revegetation has been reported (Fuentes et al., 2006; Mabuhay et al., 2006; Deng et al., 2010; Xu et al., 2010).

Remediation of acidification requires the use of amendments capable of raising the soil $\mathrm{pH}$ value. Reclamation of acidic infertile soils through different conservation and amendment practices improves soil biological fertility by increasing microbial biomass and enzymatic activity, which are beneficial to plant growth and crop production. Minimum or zero tillage also increase soil microbial biomass and enzymatic activities of degraded soils (Acosta-Martínez et al., 2003; Fuentes et al., 2006), but the potential effectiveness of this conservative practice in combination with liming agents on microbial biomass and enzymatic activities of acidic soils, is still poorly understood. We hypothesized that combination of no tillage and sugar beet foam amendment could have the potential to restore chemical fertility and increase microbial biomass and enzyme activities of a degraded acidic soil. We tested the working hypothesis by analyzing soils from a field trial established in 2002 on soils from the Cañamero's raña, characterized by low SOM content and P availability, and Al toxicity (Espejo and Cox, 1992). Information on the potentials of the adopted management can be useful as a model for soil reclamation of the Spanish 'raña', furthermore considering the large amount of SF produced worldwide, which does not find any sustainable use and must be disposed, with additional expense by the beet industry. Because the neutralization effects of organic amendments on soil $\mathrm{pH}$ value depend not only on its alkalinity but also on its $\mathrm{N}$ content and $\mathrm{N}$ mineralization processes, the positive effects of SF amendment of the Cañamero raña soil, long-term depend on both soil buffering capacity and intensity of $\mathrm{N}$ turnover. Inorganic $\mathrm{N}$ availability in soil is regulated by the rate of organic $\mathrm{N}$ mineralization (e.g. soil organic matter, crop residues, manure, chitin), catalyzed by extracellular enzymatic activities such as urease and glucosaminidase that release inorganic $\mathrm{N}$ from urea and amino-sugars, from which $\mathrm{N}$ is rapidly mineralized to inorganic $\mathrm{N}$ (Gooday 1994). Urease and glucosaminidase activities are influenced by soil physico-chemical properties and soil management and are generally inhibited by acidic soil pH values (Wang et al., 2003). Because an increase of $\mathrm{N}$-mineralizing enzyme activity can result in soil acidification, the importance of the present study relies on the fact that we assessed both the effects of the SF alkalinity and of enzymes involved in $\mathrm{N}$ turnover to understand the potentials of long term beneficial effects of SF on pH and fertility of the Cañamero raña soil.

\section{Materials and methods}

\subsection{Experimental site and agronomical management}

The study was conducted on an experimental plot established in 2002 in the Cañamero's Raña $\left(39^{\circ} 22^{\prime}-39^{\circ} 17^{\prime}, 5^{\circ} 21^{\prime} \mathrm{N}-5^{\circ} 16^{\prime}, \mathrm{E}\right)$ where soils are located $580 \mathrm{~m}$ a.s.l. on a longitudinal slope $(<1 \%)$. Based on Köppen classification, the climate of the area is moist Mediterranean (Csa), with mean annual temperature of $15.0^{\circ} \mathrm{C}$, annual precipitation of $870 \mathrm{~mm}$, and Penman-Monteith evapotranspiration rate of $1248 \mathrm{~mm}$.

Soils of the Cañamero's Raña area are classified as clay-skeletal, kaolinitic, acid, thermic Plinthic Palexerult. Soil $\mathrm{pH}$ values are in the range 5.1-5.3 in the top $5 \mathrm{~cm}$ and $4.4-4.6$ at $15 \mathrm{~cm}$ depth. Soils have low content in exchangeable bases, Al-dominated exchange complex, low bioavailable $\mathrm{P}$ and high content in rock fragments (Espejo and Cox, 1992; Gómez-Paccard et al., 2013). Main chemical and physical properties are showed in Table 1.

The long term effects of sugar foam (SF) on the properties of the Cañamero's Raña soil was tested with a field experiment established in 2002. The SF amendment was applied at rate of

Table 1

Physico-chemical properties of the soil.

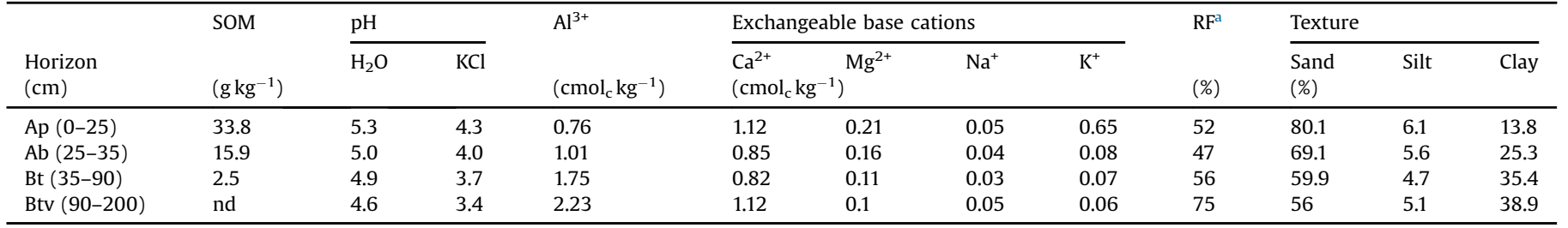

a $\mathrm{RF}=$ rock fragments $(>2 \mathrm{~mm}$; mainly $2-30 \mathrm{~cm})$. 
3.9 Mg dry product ha ${ }^{-1}$ in 2002 and in 2010 . Chemical composition of the SF amendment is reported in Table 2. The experimental design was a split-plot with four replicates and a total of 16 plots of $6 \mathrm{~m} \times 12 \mathrm{~m}$ each. The factors tested were application or not of sugar foam (SF) as Ca-amendment and control (C) and crop-tillage factors tested in the subplots: no tilled improved pasture (no tilledIP) and conventional tillage forage crop (tilled-FC). In the no tilledIP plots, the plants introduced to improve pasture quality were: Trifolium vesiculosum "Zulu", Trifolium subterraneo "Dalkeith", Trifolium subterraneo "Seaton park" ( $2 \mathrm{~kg} \mathrm{ha}^{-1}$ each), T balansae "Volta", Biserrula pelicinus "Casbah", Ornithopus compressus "Avila" (3 $\mathrm{kg} \mathrm{ha}^{-1}$ each), Lolium rigidum "Wimmera", Dactylis glomerata "Curie" $4 \mathrm{~kg} \mathrm{ha}^{-1}$ each). The FC plots were sown in the last 5 years with Oat (Avena sativa $\mathrm{L}$.) + Triticale $(\times$ Triticosecale $)+$ Vetch (Vicia sativa L.) every fall at rate of $140 \mathrm{~kg} \mathrm{ha}^{-1}$. All plots were equally fertilized every autumn, with $70 \mathrm{~kg} \mathrm{~N} \mathrm{ha}^{-1}, 70 \mathrm{~kg} \mathrm{P} \mathrm{ha}^{-1}$ and $70 \mathrm{~kg} \mathrm{Kha}^{-1}$ in the first year and $35 \mathrm{~kg} \mathrm{Nha}^{-1}, 50 \mathrm{~kg} \mathrm{Pha}^{-1}$ and $70 \mathrm{~kg} \mathrm{Kha}^{-1}$ in the following years. Crops were harvested every year in July and straw was incorporated into soil in the no tilled-IP plots and removed in the tilled-FC plots.

\subsection{Soil analysis}

Soils were sampled from all plots in October 2009, after 7 years since the first SF application and in October 2011, one year after the second SF treatment. Soil were sampled after harvest from the 0 $5 \mathrm{~cm}$ and $5-15 \mathrm{~cm}$ soil depths, and field moist samples from each plot and depth were passed through a $2 \mathrm{~mm}$ sieve and divided into two subsamples. Subsamples for microbiological and enzymatic activity analyses were immediately stored at $4{ }^{\circ} \mathrm{C}$ and subsamples for chemical analyses were air-dried.

Soil $\mathrm{pH}$ value was determined in deionized water (1:2.5 soil/ water ratio). Exchangeable $\mathrm{Ca}, \mathrm{Mg}$, $\mathrm{Na}$ and $\mathrm{K}$ concentrations were determined by soil extractions with ammonium acetate at $\mathrm{pH} 7$ followed by elemental analysis by atomic absorption spectrophotometry. The total $\mathrm{C}$ and $\mathrm{N}$ content was determined with a LECO Instruments TruSpec $\mathrm{CN}$ analyser. The $\beta$-glucosidase activity (Gls) was measured according to Strobl and Traunmüller (1996). The $\beta$-glucosaminidase activity ( $\mathrm{Glm}$ ) was measured according to Parham and Deng (2000). The dehydrogenase activity (DHA) was measured according to García et al. (1993). The urease activity (Ure) was measured according to Kandeler and Gerber (1988). The

Table 2

Chemical composition of the SF amendment.

\begin{tabular}{ll}
\hline Component & $\begin{array}{l}\text { Concentration } \\
\left(\mathrm{g} \mathrm{kg}^{-1}\right)\end{array}$ \\
\hline $\mathrm{CaO}$ & 437 \\
$\mathrm{SO}_{4}{ }^{2-}$ & 5.1 \\
$\mathrm{SiO}_{2}$ & 17.3 \\
$\mathrm{P}_{2} \mathrm{O}_{6}$ & 8.1 \\
$\mathrm{MgO}$ & 47.3 \\
$\mathrm{~F}^{-}$ & $\mathrm{ND}$ \\
$\mathrm{Al}_{2} \mathrm{O}_{3}$ & 24.2 \\
$\mathrm{~K}_{2} \mathrm{O}$ & 1.95 \\
$\mathrm{Fe}_{2} \mathrm{O}_{3}$ & 1.9 \\
$\mathrm{Na}_{2} \mathrm{O}$ & 1.05 \\
$\mathrm{TiO}_{2}$ & $\mathrm{nd}$ \\
$\mathrm{MnO}$ & 47.3 \\
$\mathrm{OM}^{\mathrm{Lime}}$ & 86.7 \\
$\mathrm{Active}$ lime & 765 \\
$\mathrm{LOI}^{\mathrm{c}}$ & 213 \\
$\mathrm{pH}^{\mathrm{b}}(1: 5$ water solution) & 467.6 \\
\hline
\end{tabular}

a Total Ca equivalent.

${ }^{b} \mathrm{CaCO}_{3}$ reactive with ammonium oxalate.

c Loss on ignition. microbial biomass carbon $(\mathrm{MBC})$ was estimated by the substrate induced respiration (SIR) method (Anderson and Domsch, 1978).

Statistical analysis of the data was conducted with Statgraphics Centurion XVI. Analyses of variance were performed using a linear model for a split-plot design with blocks for Ca-amendment as the main factor and crop-tillage as secondary factor. Log transformations were applied when necessary to meet ANOVA assumptions. Data were analysed independently for each soil depth. A correlation matrix of different properties was based on Pearson correlation coefficients $(\mathrm{p}<0.01$ and $\mathrm{p}<0.05)$.

\section{Results}

\subsection{Soil $p H$ value and exchangeable bases}

Seven years since the first Ca-amendment application, $\mathrm{pH}$ soil values were significantly higher in amended plots than in control plots for both $0-5 \mathrm{~cm}$ and $5-15 \mathrm{~cm}$ soil layers (Table 3 ). The differences between amended and unamended soils were increased after the second Ca-amendment application for both soil layers. Significant alkalinization in the SF treatment was observed between pasture use and forage soil use in soils sampled in 2009 from the $5-15 \mathrm{~cm}$ layer (Table 3 ). Among the exchangeable base cations, $\mathrm{Ca}$ and $\mathrm{Mg}$ concentrations were increased in SF treatments as compared to the control soils and on both sampling dates, with the highest values observed in soils sampled in 2011 from the SF plots (Table 3). The exchangeable Na concentrations were higher in soils sampled in 2009 than those sampled in 2011 in all treatments and layers and $\mathrm{K}$ followed the same pattern in the upper layer (Table 3).

\subsection{Total organic carbon and total nitrogen}

In the $0-5 \mathrm{~cm}$ layer TOC was influenced by soil use (Table 3 ). TOC value was $14 \%$ higher in the no tilled-IP samples than in the tilled-FC samples analyzed in 2009 , but when we compared to soils sampled in 2011, the difference increased by $40 \%$. Higher TOC content was observed in SF soil as compared with C plots in 2009 in the 5-15 layer $(P<0.05)$. An interaction between the amendment and tillage factors occurred in the $0-5 \mathrm{~cm}$ layer $(P<0.05)$ in both sampling times, being the value for no tilled-IP + amended higher and with no differences between the rest treatments.

Total nitrogen (TN) concentrations followed the trend of TOC, with higher values in the no tilled-IP plots than in tilled-FC plots regardless of sampling times and soil layer (Table 3 ). The TOC/TN ratio values were not affected by the Ca-amendment or the use in both depths and samplings.

\subsection{Microbial biomass and enzymatic activities}

Soil MBC was significantly higher in the no tilled-IP plots than in the tilled-FC plots in the $0-5 \mathrm{~cm}$ layer of soil sampled in 2011 (Table 4). Differently, in the $5-15 \mathrm{~cm}$ layer MBC was higher in the tilled-FC treatment than in the no tilled-IP (Table 4). The Caamendment in the $0-5 \mathrm{~cm}$ layer had no effect on $\mathrm{MBC}$ regardless of both samplings times. The MBC/TOC ratio showed similar values among the treatments in the $0-5 \mathrm{~cm}$ soil layer, with higher values in soils sampled in 2009, whereas in the $5-15 \mathrm{~cm}$ layer showed no specific trend in relation to treatments and lower values than soils sampled from the upper layer, particularly in 2011 (Table 4).

Enzyme activities were higher in the $0-5 \mathrm{~cm}$ than in the 5$15 \mathrm{~cm}$ soil layers in soils sampled both in 2009 and 2011 (Table 4). After 7 years since the Ca-amendment application (2009 sampling), values of Gls and Glm showed no trends among the treatments, whereas higher values of DHA activity were observed in amended than in control soils at both $0-5$ and $5-15 \mathrm{~cm}$ soil 
Table 3

Mean values of chemical properties of soils under different treatments, sampled in 2009 and 2011 from the 0-5 and 5-15 cm depths.

\begin{tabular}{|c|c|c|c|c|c|c|c|c|c|c|c|c|c|c|c|c|c|}
\hline \multirow[b]{2}{*}{$\begin{array}{l}\text { Soil depth } \\
(\mathrm{cm})\end{array}$} & \multirow[b]{2}{*}{ Treatments } & \multicolumn{2}{|l|}{$\mathrm{pH}$} & \multicolumn{2}{|l|}{ TOC } & \multicolumn{2}{|l|}{ TN } & \multicolumn{2}{|c|}{ TOC/TN } & \multicolumn{2}{|l|}{$\mathrm{Ca}$} & \multicolumn{2}{|l|}{$\mathrm{Mg}$} & \multicolumn{2}{|l|}{$\mathrm{Na}$} & \multicolumn{2}{|l|}{ K } \\
\hline & & 2009 & 2011 & $\begin{array}{l}2009 \\
\left(\mathrm{~g} \mathrm{~kg}^{-1}\right)\end{array}$ & 2011 & $\begin{array}{l}2009 \\
\left(\mathrm{~g} \mathrm{~kg}^{-1}\right)\end{array}$ & 2011 & 2009 & 2011 & $\begin{array}{l}2009 \\
\mathrm{cmol}_{\mathrm{c}} \mathrm{k}\end{array}$ & $g^{-1}$ & $\begin{array}{l}2009 \\
\mathrm{cmol}_{\mathrm{c}} \mathrm{kg}\end{array}$ & $g^{2011}$ & $\begin{array}{l}2009 \\
\mathrm{cmol}_{\mathrm{c}} \mathrm{kg}\end{array}$ & 2011 & $\begin{array}{l}2009 \\
\mathrm{cmol}_{\mathrm{c}} \mathrm{kg}\end{array}$ & 2011 \\
\hline \multirow[t]{8}{*}{$0-5$} & Use & & & & & & & & & & & & & & & & \\
\hline & No tilled-IP & 5.9 & 6.2 & 46.3 & 61.3 & 2.7 & 2.9 & 17.0 & 20.4 & 3.52 & 3.94 & 0.76 & 1.34 & 0.10 & 0.035 & 0.51 & 0.41 \\
\hline & $\begin{array}{l}\text { Tilled-FC } \\
\text { Amendment }\end{array}$ & 5.7 & 6.1 & 40.7 & 44.0 & 2.7 & 2.0 & 15.5 & 20.0 & 2.32 & 3.18 & 0.44 & 0.78 & 0.09 & 0.031 & 0.40 & 0.20 \\
\hline & $\mathrm{C}$ & 5.6 & 5.4 & 42.2 & 52.2 & 2.5 & 2.4 & 17.1 & 20.2 & 1.59 & 1.72 & 0.22 & 0.78 & 0.12 & 0.035 & 0.44 & 0.35 \\
\hline & $\begin{array}{l}\text { SF } \\
\text { Effects }\end{array}$ & 6.1 & 6.9 & 44.8 & 53.0 & 2.9 & 2.5 & 15.4 & 20.2 & 4.25 & 5.40 & 0.98 & 1.34 & 0.07 & 0.031 & 0.48 & 0.25 \\
\hline & $\mathrm{U}^{\mathrm{a}}$ & ns & ns & $* * *$ & $* * *$ & ns & $* * *$ & ns & ns & ns & $* *$ & $*$ & $* *$ & ns & ns & $* *$ & $*$ \\
\hline & $A^{b}$ & $* *$ & $* *$ & ns & ns & ns & ns & ns & ns & $*$ & $* * *$ & $* *$ & $* *$ & ns & ns & ns & ns \\
\hline & $\mathrm{UxA}^{\mathrm{c}}$ & ns & ns & $*$ & $*$ & ns & ns & ns & ns & ns & ns & ns & ns & ns & ns & ns & ns \\
\hline \multirow[t]{8}{*}{$5-15$} & Use & & & & & & & & & & & & & & & & \\
\hline & No tilled-IP & 5.8 & 5.7 & 35.6 & 37.2 & 2.2 & 1.7 & 16.2 & 21.4 & 2.20 & 2.75 & 0.30 & 0.38 & 0.09 & 0.019 & 0.24 & 0.25 \\
\hline & $\begin{array}{l}\text { Tilled-FC } \\
\text { Amendment }\end{array}$ & 5.4 & 5.4 & 35.9 & 36.9 & 2.0 & 1.7 & 17.1 & 21.7 & 1.90 & 2.50 & 0.25 & 0.40 & 0.09 & 0.022 & 0.23 & 0.23 \\
\hline & C & 5.4 & 5.1 & 34.9 & 36.8 & 2.0 & 1.7 & 16.9 & 21.4 & 1.25 & 1.18 & 0.10 & 0.15 & 0.09 & 0.017 & 0.24 & 0.21 \\
\hline & $\begin{array}{l}\text { SF } \\
\text { Effects }\end{array}$ & 5.7 & 6.0 & 36.5 & 37.3 & 2.2 & 1.7 & 16.4 & 21.7 & 2.86 & 4.07 & 0.45 & 0.63 & 0.09 & 0.024 & 0.24 & 0.27 \\
\hline & $\mathrm{U}^{\mathrm{a}}$ & $*$ & ns & Ns & ns & ns & ns & ns & ns & ns & ns & ns & ns & ns & ns & ns & ns \\
\hline & $A^{b}$ & $* *$ & $* *$ & $*$ & ns & ns & ns & ns & ns & $*$ & $*$ & $* *$ & $* *$ & ns & ns & ns & ns \\
\hline & $\mathrm{UxA}^{\mathrm{c}}$ & ns & ns & ns & ns & ns & ns & ns & ns & ns & ns & ns & ns & ns & ns & ns & ns \\
\hline
\end{tabular}

a Differences among soil Use (No tilled-IP vs Tilled-FC).

b Differences among soil Amendment (C vs SF).

c Intecations among both factos.

Table 4

Mean values of microbial biomass and enzyme activities of soils under different treatments, sampled in 2009 and 2011 from the $0-5$ and 5-15 cm depths.

\begin{tabular}{|c|c|c|c|c|c|c|c|c|c|c|c|c|c|}
\hline \multirow[b]{2}{*}{$\begin{array}{l}\text { Soil depth } \\
(\mathrm{cm})\end{array}$} & \multirow[b]{2}{*}{ Treatments } & \multicolumn{2}{|l|}{$\mathrm{MBC}$} & \multicolumn{2}{|c|}{ MBC/TOC } & \multicolumn{2}{|c|}{$\beta$-glucosidase } & \multicolumn{2}{|l|}{ DHA } & \multicolumn{2}{|c|}{ Glucosaminidase } & \multicolumn{2}{|c|}{ Urease } \\
\hline & & $\begin{array}{l}2009 \\
(\mathrm{mg} \mathrm{kg}\end{array}$ & $\begin{array}{l}2011 \\
-1)\end{array}$ & $\begin{array}{l}2009 \\
(\%)\end{array}$ & 2011 & $\begin{array}{l}2009 \\
(\mathrm{mg} \mathrm{s}\end{array}$ & $\begin{array}{l}2011 \\
\left.\mathrm{~kg}^{-1} 3 \mathrm{~h}^{-1}\right)\end{array}$ & $\begin{array}{l}2009 \\
(\mathrm{mmo}\end{array}$ & $\begin{array}{l}2011 \\
\left.\mathrm{Fg}^{-1} \mathrm{~h}^{-1}\right)\end{array}$ & $\begin{array}{l}2009 \\
(\mathrm{mg} \mathrm{p}\end{array}$ & $\begin{array}{l}2011 \\
\left.\text { enol } g^{-1} h^{-1}\right)\end{array}$ & $\begin{array}{l}2009 \\
(\mathrm{mmo}\end{array}$ & $\begin{array}{l}2011 \\
\left.-\mathrm{N} \mathrm{kg}^{-1} \mathrm{~h}^{-1}\right)\end{array}$ \\
\hline \multirow[t]{8}{*}{$0-5$} & Use & & & & & & & & & & & & \\
\hline & No tilled-IP & 5341 & 5643 & 11.6 & 9.4 & 270 & 645 & 0.007 & 0.013 & 1269 & 2183 & 53.6 & 58.0 \\
\hline & $\begin{array}{l}\text { Tilled FC } \\
\text { Amendment }\end{array}$ & 5040 & 3520 & 12.3 & 7.6 & 271 & 345 & 0.006 & 0.014 & 1272 & 1312 & 41.8 & 36.3 \\
\hline & $\mathrm{C}$ & 5126 & 5190 & 12.2 & 9.3 & 254 & 474 & 0.005 & 0.006 & 1266 & 1686 & 44.3 & 44.0 \\
\hline & $\begin{array}{l}\text { SF } \\
\text { Effects }\end{array}$ & 5225 & 4973 & 11.8 & 7.7 & 286 & 516 & 0.009 & 0.021 & 1275 & 1810 & 51.0 & 50.3 \\
\hline & $\mathrm{U}^{\mathrm{a}}$ & ns & $* * *$ & ns & $*$ & ns & $* *$ & ns & ns & ns & $* * *$ & $*$ & $* * *$ \\
\hline & $A^{b}$ & ns & ns & ns & ns & ns & ns & $* *$ & $* * *$ & ns & ns & ns & ns \\
\hline & $\mathrm{UxA}^{\mathrm{c}}$ & ns & ns & ns & ns & ns & ns & ns & ns & ns & $*$ & ns & $*$ \\
\hline \multirow[t]{8}{*}{$5-15$} & Use & & & & & & & & & & & & \\
\hline & No tilled-IP & 3140 & 1303 & 8.9 & 3.6 & 88 & 154 & 0.003 & 0.005 & 668 & 670 & 13.7 & 13.7 \\
\hline & $\begin{array}{l}\text { Tilled FC } \\
\text { Amendment }\end{array}$ & 3566 & 1670 & 10.0 & 4.9 & 141 & 168 & 0.003 & 0.004 & 802 & 629 & 15.6 & 12.6 \\
\hline & $\mathrm{C}$ & 3666 & 1882 & 10.6 & 5.4 & 107 & 140 & 0.002 & 0.002 & 675 & 551 & 13.9 & 11.5 \\
\hline & $\begin{array}{l}\text { SF } \\
\text { Effects }\end{array}$ & 3040 & 1191 & 8.3 & 3.2 & 123 & 181 & 0.004 & 0.006 & 796 & 747 & 15.3 & 14.9 \\
\hline & $\mathrm{U}^{\mathrm{a}}$ & ns & $*$ & ns & ns & $* *$ & ns & ns & ns & ns & ns & ns & ns \\
\hline & $\mathrm{A}^{\mathrm{b}}$ & * & $*$ & $*$ & $*$ & ns & $*$ & $*$ & $* *$ & ns & $* *$ & ns & $* *$ \\
\hline & $\mathrm{UxA}^{\mathrm{c}}$ & ns & ns & ns & ns & ns & ns & $*$ & ns & ns & ns & ns & ns \\
\hline
\end{tabular}

\footnotetext{
a Differences among soil Use (No tilled-IP vs Tilled-FC).

b Differences among soil Amendment (C vs SF).

c Intecations among both factos.
}

depths (Table 4). The Urease activity values were higher in no tilled-IP than in tilled-FC in the $0-5 \mathrm{~cm}$ soil layer, whereas no significant differences were found when amended plots were compared with control plots in 2009 sampling at both layers (Table 4). In soil sampled in 2011, a significant increase of Gls, Glm and Urease activities was observed in no tilled-IP soil as compared to tilled-FC in the $0-5 \mathrm{~cm}$ soil layer (Table 4). Dehydrogenase activity was higher in amended than in control soil at both depths, showing a significant effect of the soil $\mathrm{pH}$ value on this enzyme activity, whereas the effect of the soil $\mathrm{pH}$ on the other measured enzyme activities was less evident (Table 4). Significant interaction between soil use and amendment factors was found for Glm and Ure in the $0-5 \mathrm{~cm}$ layer $(P<0.05)$ in 2011 sampling, with the highest value for no tilled-IP + SF and with not differences between the rest treatments.

The dehydrogenase was significantly correlated $(P<0.001)$ with the soil $\mathrm{pH}$ for both soil depths and samplings, particularly in soils sampled in 2011, but was not correlated with TOC and TN (Tables 5-8 ). Significant $(P<0.001)$ correlations between Gls, Glm and Ure activities were found in the $0-5 \mathrm{~cm}$ soil layer of the 2011 
Table 5

Correlation coefficients between biochemical properties, $\mathrm{pH}$, total organic carbon and total nitrogen for samples from $2009(0-5 \mathrm{~cm})$.

\begin{tabular}{|c|c|c|c|c|c|c|c|c|}
\hline & Gls & DHA & Glm & Ure & $\mathrm{MBC}$ & TOC & TN & $\mathrm{pH}$ \\
\hline Gls & & ns & ns & ns & $0.63^{* *}$ & ns & $0.80^{* * *}$ & ns \\
\hline DHA & & & ns & ns & ns & ns & ns & $0.75^{\text {**** }}$ \\
\hline Glm & & & & ns & ns & ns & ns & ns \\
\hline Ure & & & & & ns & $0.73^{* *}$ & ns & ns \\
\hline MBC & & & & & & ns & $0.58^{*}$ & ns \\
\hline TOC & & & & & & & $0.60^{*}$ & ns \\
\hline $\mathrm{TN}$ & & & & & & & & ns \\
\hline
\end{tabular}

Table 6

Correlation coefficients between biochemical properties, $\mathrm{pH}$, total organic carbon and total nitrogen for samples from 2009 (5-15 cm).

\begin{tabular}{|c|c|c|c|c|c|c|c|c|}
\hline & Gls & DHA & Glm & Ure & MBC & TOC & TN & $\mathrm{pH}$ \\
\hline Gls & & ns & $0.60^{*}$ & ns & ns & ns & ns & ns \\
\hline DHA & & & ns & ns & ns & ns & ns & $0.69^{* *}$ \\
\hline Glm & & & & ns & ns & ns & ns & ns \\
\hline Ure & & & & & ns & $0.80^{* * *}$ & ns & ns \\
\hline $\mathrm{MBC}$ & & & & & & ns & ns & ns \\
\hline TOC & & & & & & & $0.55^{*}$ & ns \\
\hline $\mathrm{TN}$ & & & & & & & & ns \\
\hline
\end{tabular}

Table 7

Correlation coefficients between biochemical properties, $\mathrm{pH}$, total organic carbon and total nitrogen for samples from $2011(0-5 \mathrm{~cm})$.

\begin{tabular}{|c|c|c|c|c|c|c|c|c|}
\hline & Gls & DHA & Glm & Ure & $\mathrm{MBC}$ & TOC & TN & $\mathrm{pH}$ \\
\hline Gls & & ns & $0.93^{* * *}$ & $0.91^{* * *}$ & $0.71^{* *}$ & $0.91^{* * *}$ & $0.90^{* * *}$ & ns \\
\hline DHA & & & ns & ns & ns & ns & ns & $0.98^{* * *}$ \\
\hline Glm & & & & $0.84^{* * *}$ & $0.65^{*}$ & $0.78^{* * * *}$ & $0.83^{* * *}$ & ns \\
\hline Ure & & & & & $0.67^{* *}$ & $0.84^{* * *}$ & $0.84^{* * *}$ & ns \\
\hline MBC & & & & & & $0.75^{* *}$ & $0.73^{* *}$ & ns \\
\hline TOC & & & & & & & $0.95^{* * *}$ & ns \\
\hline $\mathrm{TN}$ & & & & & & & & ns \\
\hline
\end{tabular}

Table 8

Correlation coefficients between biochemical properties, $\mathrm{pH}$, total organic carbon and total nitrogen for samples from $2011(5-15 \mathrm{~cm})$.

\begin{tabular}{|c|c|c|c|c|c|c|c|c|}
\hline & Gls & DHA & Glm & Ure & MBC & TOC & TN & $\mathrm{pH}$ \\
\hline Gls & & $0.71^{* *}$ & $0.52^{*}$ & $0.53^{*}$ & ns & ns & $\mathrm{ns}$ & $0.58^{*}$ \\
\hline DHA & & & $0.62 *$ & $0.65^{* *}$ & ns & ns & ns & $0.92^{\text {**** }}$ \\
\hline Glm & & & & ns & ns & $0.69^{* *}$ & ns & $0.60^{* *}$ \\
\hline Ure & & & & & ns & ns & ns & $0.54^{*}$ \\
\hline MBC & & & & & & ns & ns & ns \\
\hline TOC & & & & & & & ns & ns \\
\hline TN & & & & & & & & ns \\
\hline
\end{tabular}

sampling, and of Gls, Glm and Ure activities with MBC, TOC and TN (Table 7).

\section{Discussion}

The higher TOC content in the $0-5 \mathrm{~cm}$ layer of the no tilled-IP soil compared to the tilled-FC soil showed that conservative practices are effective in stabilizing SOM in degraded soils. On the other hand, the interactions use-amendment confirmed that $\mathrm{Ca}$ can have positive cooperative effects on SOM stabilization, as supported by previously published results (Briedis et al., 2012; Gómez-Paccard et al., 2013) and particularly in no tilled soils where Ca can stabilize the aggregate cements (Gómez-Paccard et al., 2013). However, the relatively small changes in TOC and TN in relation to soil amendment and tillage were likely due to the short experimental period ( 9 years), as compared to time required for a steady increase of soil organic matter in soils under reduced tillage. Analysis of soils sampled in 2009 showed that amendment with SF had a long-term neutralization effect on soil $\mathrm{pH}$, which was enhanced by a second application in 2011. These results were in line with those previously reported (Caires et al., 2006; GómezPaccard et al., 2013). Most of the Ca was retained in the $0-5 \mathrm{~cm}$ soil layer, particularly in no tilled soils. This result parallels previous findings on the beneficial effects of conservation tillage on $\mathrm{C}, \mathrm{N}$ and other nutrients retention in soil (Soane et al., 2012). It also suggests that the Ca-amendment is not as important as tillage on organic carbon, possibly as a result of the destruction of aggregates, which exposed the SOM to mineralization.

Amelioration of soil acidity and SOM accumulation, particularly in the absence of plowing disturbance, have led to increased microbial biomass likely due to the quality increase in soil microbial habitat (Miller and Jastrow, 1990; Tisdall, 1991). Moreover, an increased plant cover and growth could have also sustained microbial community and microbial activity through the release of root exudates (Renella et al., 2007b). Indeed, soils, like natural habitats, have a maximum carrying capacity which results from the interaction between the soil structure and aggregates, nutrient availability (Griffiths and Jones, 1965) and plant/microbe ecological interactions (e.g. symbioses, root association). Increased microbial biomass and microbial activity in response to liming on acidic soils has been widely reported (Neale et al., 1997; Stenberg et al., 2000; Anderson and Nilsson, 2011; Bezdireck et al., 2003; Ekenler and Tabatabai, 2003; Fuentes et al., 2006). The higher activities of $\beta$-glucosidase and $\beta$-glucosaminidase in no-tilled compared with tilled soil was in agreement with the higher MBC, which indicate a higher capability of the soil microorganisms to metabolize carbohydrates in soil (Acosta-Martínez et al., 2008).

Dehydrogenase activity in soil is considered as an indicator of the overall microbial respiration processes, and it's generally positively correlated with the soil $\mathrm{pH}$ value and SOM content (García et al., 1997; Quilchano and Marañón, 2002). Increased dehydrogenase activity under conservation tillage as compared to traditional tillage has been also reported (Acosta-Martínez et al., 2008; López-Garrido et al., 2012), as well as an increase of enzyme activities in limed soils (Acosta-Martínez and Tabatabai, 2000; Stenberg et al., 2000; Ekenler and Tabatabai, 2003). Alleviation of Al toxicity through $\mathrm{pH}$ neutralization and formation of $\mathrm{Al}-\mathrm{OM}$ compounds (Gómez-Paccard et al., 2013) could be another factor enhancing the microbial activity and enzyme activities in the SF amended plots, as reported by Ekenler and Tabatabai (2003). Stronger stimulation of the soil $\beta$-glucosidase and glucosaminidase than urease activity reflects the quality of the amendment used. In fact, SF is rich in cell wall polysaccharides such as cellulose, pectin and other hemicelluloses, whose decomposition requires the action of glycolytic enzymes to process the polymeric saccharides and also the mineralization of organic $\mathrm{N}$ to meet the microbial metabolic nutrient demand during SF decomposition (Sinsabaugh et al., 2009). The observed trends of the measured soil enzyme activities have also implications on the long-term neutralization effects of SF, as the effects of organic amendments on soil $\mathrm{pH}$ value depend not only on its original alkalinity (e.g. base cations concentration), but also on their content of $\mathrm{N}$, as $\mathrm{N}$ mineralization contributes to changes of the soil $\mathrm{pH}$ value through ammonification and nitrification processes (Turmel et al., 2015). Therefore, the prolonged neutralizing effect on the $\mathrm{pH}$ value of the studied Cañamero's raña soil could be the result of both the increased $\mathrm{Ca}$ and $\mathrm{Mg}$ concentrations in soil due to its content of active or readily soluble lime $(21.3 \%)$, and the reduced $\mathrm{N}$ mineralization. However, direct measurement of $\mathrm{N}$ mineralization should be conducted to evaluate the relative importance of turnover on $\mathrm{pH}$ buffering capacity of the studied soils. 


\section{Conclusions}

Our work demonstrated that SF is an effective liming agent that leads to amelioration of the Cañamero's raña soils in terms of $\mathrm{pH}$ neutralization, organic matter, microbial biomass and enzymatic activity. Soil amelioration is predicted to be permanent due to both the high SF lime content and limited nitrifications in the studied soils, but there are also additional benefits from conservative soil management. Overall, the incorporation of SF is a sustainable technique to induce physical, chemical and biological fertility in Spanish acidic raña soils.

\section{Acknowledgements}

Support for this work was provided by the Spanish Ministry of Science and Innovation (Projects CGL-2008-04361-C02-01, AGL2012-39498) and the Community of Madrid Regional Government (Project AGRISOST S2009/AGR-1630). The authors are grateful to Pedro González and Rafaela Ordóñez for their collaboration and support.

\section{References}

Acosta-Martínez, V., Tabatabai, M.A., 2000. Enzymes activities in a limed agricultural soil. Biol. Fertil Soils 31, 85-91.

Acosta-Martínez, V., Zobeck, T.M., Gill, T.E., Kennedy, A.C., 2003. Enzyme activities and microbial community structure in semiarid agricultural soils. Biol. Fertil. Soils 38, 216-227.

Acosta-Martínez, V., Acosta-Mercado, D., Sotomayor-Ramírez, D., Cruz-Rodríguez L., 2008. Microbial communities and enzymatic activities under different management in semiarid soils. Appl. Soil Ecol. 38, 249-260.

Anderson, J.P.E., Domsch, K.H., 1978. A physiological method for the quantitative measurement of microbial biomass in soils. Soil Biol. Biochem. 14, 273-279.

Anderson, S., Nilsson, S.I., 2011. Influence of pH and temperature on microbial activity, substrate availability of soil-solution bacteria and leaching of dissolved organic carbon in a mor humus. Soil Biol. Biochem. 33 1181-1119.

Bezdireck, D.F., Beaver, T., Granatstein, D., 2003. Subsoil ridge tillage and lime effects on soil microbial activity, soil pH, erosion, and wheat and pea yield in the Pacific Northwest, USA. Soil Tillage Res. 64, 55-63.

Briedis, C., de Moraes Sá, J.C., Caires, E.F., de Fátima Navarro, J., Inagaki, T.M., Boer, A., de Oliveira Ferreira, A., Neto, C.Q., Canalli, L.B., Bürkner dos Santos, J., 2012. Changes in organic matter pools and increases in carbon sequestration in response to surface liming in an oxisol under long-term no-till. Soil Sci. Soc. Am. J. 76, 151-160.

Caires, E., Barth, G., Garbuio, F., 2006. Lime application in the establishment of a no till system for grain crop production in Southern Brazil. Soil Tillage Res. 89, 312.

Deng, H., Zhang, B., Yin, R., Wang, H., Mitchell, S.M., Griffiths, B.S., Daniell, T.J., 2010. Long-term effect of re-vegetation on the microbial community of a severely eroded soil in sub-tropical China. Plant Soil 328, 447-458.

Ekenler, M., Tabatabai, M.A., 2003. Effects of liming and tillage systems on microbial biomass and glycosidases in soils. Biol. Fertil. Soils 39, 51-61.

Espejo, R., Cox, F., 1992. Factors affecting phosphorus sorption in Palexerults of western Spain. Commun. Soil Sci. Plant Anal. 23, 389-398.

Fuentes, J.P., Bezdicek, D.F., Flury, M., Albrecht, S.A., Smith, J.L., 2006. Microbial activity affected by lime in a long-term no-till soil. Soil Tillage Res. 88, 123-131.

García, C., Hernández, T., Costa, F., Ceccanti, B., Masciandaro, G., 1993. The dehydrogenase activity of soil as an ecological marker in processes of perturbed system regeneration. In: Gallardo-Lancho, J. (Ed.), Proceedings of the XI International Symposium of Environmental Biochemistry. CSIC, Salamanca, España, pp. 89-100.

García, C., Hernández, T., Costa, F., 1997. Potencial use of dehydrogenase activity as an index of microbial activity in degraded soils. Commun. Soil Sci. Plant Anal. 1, 123-134.

Garrido, F., Illera, V., Vizcayno, C., Garcia-Gonzalez, M.T., 2003. Evaluation of industrial by-products as soil acidity amendments: chemical and mineralogical implications. Eur. J. Soil Sci. 54, 411-422.
Gómez-Paccard, C., Mariscal-Sancho, I., León, P., Benito, M., González, P., Ordóñez, R. Espejo, R., Hontoria, C., 2013. Ca-amenedment and tillage: medium term synergies for improving key soil properties of acid soils. Soil Tillage Res. 134, 195-206.

Gooday, G.W., 1994. Physiology of microbial degradation of chitin and chitosan. In: Ratledge, C. (Ed.), Biochemistry of Microbial Degradation. Kluwer Academic, Netherlands, pp. 279-312.

Griffiths, E., Jones, D., 1965. Microbiological aspects of soil structure. I Relationships between organic amendments, microbial colonization and changes in aggregate stability. Plant Soil 23, 17-33.

Kandeler, E., Gerber, H., 1988. Short-term assay of soil urease activity using colorimetric determination of ammonium. Biol. Fertil. Soils 6, 68-72.

Kochian, L.V., Piñeros, M.A., Hoekenga, O.A., 2005. The physiology, genetics and molecular biology of plant aluminum resistance and toxicity. Plant Soil 274, 175-195.

López-Garrido, R., Deurer, M., Madejón, E., Murillo, J.M., Moreno, F., 2012. Tillage influence on biophysical soil properies: the example of a long-term tillage experiment under Mediterranean rainfed conditions in South Spain. Soil Tillage Res. 118, 52-60.

Mabuhay, J.A., Nakagoshi, N., Isagi, Y., 2006. Microbial responses to organic and inorganic amendments in eroded soils. Land Degrad. Dev. 17, 321-332.

Menzies, N.W., 2003. Toxic elements in acid soils: chemistry and measurement. In: Rengel, Z. (Ed.), Handbook of Soil Acidity. Marcel Dekker, Inc., New York, pp. 267-296.

Miller, R.M., Jastrow, J.D., 1990. Hierarchy of root and mychorryzal fungal interactions with soil aggregations. Soil Biol. Biochem. 22, 579-584.

Neale, S.P., Shah, Z., Adams, W.A., 1997. Changes in microbial biomass and nitrogen turnover in acidic organic soils following liming. Soil Biol. Biochem. 88,123-131.

Parham, J.A., Deng, S.P., 2000. Detection, quantification and characterization of $\beta$-glucosaminidase activity in soil. Soil Biol. Biochem. 32, 1183-1190.

Peregrina-Alonso, F., 2005. Valoración agronómica de residuos industriales yesíferos y calizos: Implicaciones sobre la dinámica del complejo de cambio, la disolución del suelo y la productiviad en Palexerults del Oeste de España. Univ. Politécnica de Madrid. ETSIA (Tesis Doctoral).

Quilchano, C., Marañón, T., 2002. Dehydrogenase activity in Mediterranean forest soils. Biol. Fertil. Soils 35, 102-107.

Renella, G., Landi, L., Valori, F., Nannipieri, P., 2007a. Microbial and hydrolase activity after release of low molecular weight organic compounds by a model root surface in a clayey and a sandy soil. Appl. Soil Ecol. 36, 124-129.

Renella, G., Szukics, U., Landi, L., Nannipieri, P., 2007b. Quantitative assessment of hydrolase production and persistence in soil. Biol. Fertil. Soils 44, 321-329.

Rousk, J., Bååth, E., Brookes, P.C., Lauber, C.L., Lozupone, C., Caporaso, J.G., Knight, R., Fierer, N., 2010a. Soil bacterial and fungal communities across a pH gradient in an arable soil. ISME J. 4, 1340-1351.

Rousk, J., Brookes, P.C., Bååth, E., 2010b. Investigating the mechanisms for the opposing pH-relationships of fungal and bacterial growth in soil. Soil Biol. Biochem. 42, 926-934.

Sinsabaugh, R.L., Brian, H., Hill, B.H., Follstad Shah, J.J., 2009. Ecoenzymatic stoichiometry of microbial organic nutrient acquisition in soil and sediment. Nature 462, 795-798.

Soane, B.D., Ball, B.C., Arvidsson, J., Basch, G., Moreno, F., Roger-Estrade, J., 2012. Notill in northern, western and south-western Europe: a review of problems and opportunities for crop production and the environment. Soil Tillage Res. 118, 66-87.

Stenberg, M., Stenberg, B., Rydberg, T., 2000. Effects of reduced tillage and liming on microbial activity and soil properties in a weakly-structured soil. Appl. Soil Ecol. 14, 135-145.

Strobl, W., Traunmüller, M., 1996. $\beta$-Glucosidase activity. In: Springer Labor (Ed.), Methods in Soil Biol. Springer Labor, Germany, pp. 198-200.

Tisdall, J.M., 1991. Fungal hyphae and structural stability. Aust. J. Soil Res. 29, 729_ 743.

Turmel, M., Speratti, A., Baudron, F., Verhulst, N., Govaets, B., 2015. Crop residue management and soil health: a systems analysis. Agric. Syst. 134, 6-16.

Vanderlinden, K., Polo, M.J., Ordóñez, R., Giráldez, J., 2006. Spatiotemporal evolution of soil pH and zinc after the Aznalcollar mine spill. J. Environ. Qual. 35, 37-49.

Wang, W.J., Smith, C.J., Chen, D., 2003. Towards a standardised procedure for determining the potentially mineralizable nitrogen of soil. Biol. Fertil. Soils 37 362-374.

Xu, Q., Jiang, P., Wang, H., 2010. Improvement of biochemical and biological properties of eroded red soil by artificial revegetation. J. Soils Sedim. 10, 255262. 